\title{
JO-Science
}

INTERNATIONAL JOURNAL ONLINE OF SCIENCE

Volume II, Issue IX December 2016

\section{ADDICTION OF DIGITAL GAMES}

\author{
PANKAJ \\ NET (COMPUTER SCIENCE \& APPLICATIONS) \\ B.TECH.( IT) \\ MCA \\ MBA ( IT \& MARKETING) \\ MAHARSHI DAYANAND UNIVERSITY, ROHTAK \\ HARYANA \\ INDIA
}

\begin{abstract}
Computer and mobile games playing is the most well known wellspring of excitement for individuals of all ages, however overabundance playing in these amusements causes negative results spoke to by computer games dependence. Computer games enslavement is considered as a standout amongst the most critical research field which got much consideration these days and pulled in numerous columnist and specialists to expound on and think about it top to bottom. Albeit numerous observational reviews had been drafted in this field so as to gather and investigate information identified with that field, the
\end{abstract}

issue is there is a missing of clear conclusions and results in this field. The fundamental target of this exploration is to build up a poll that aiding in measuring the level of computer games enslavement for understudies in Jordanian colleges. The survey, which utilized as a part of this exploration expects to discover the relationship between each of social issue, troubles in time administration, issues in organizing life`s exercises, and radical play with computer game addiction. 780 polls were appropriated to understudies from Jordanian college's understudies' general public. The information gathered from the respondents demonstrated the accompanying 


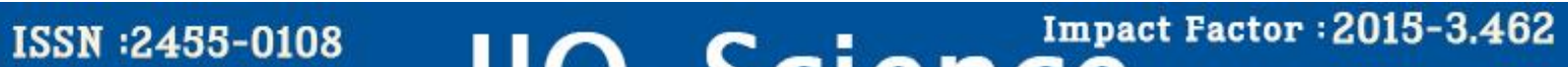

\section{INTERNATIONAL JOURNAL ONLINE OF SCIENCE}

Volume II, Issue IX December 2016

there is a huge relationship between each of the accompanying of social issue, troubles in time administration, issues in organizing life`s exercises, and unbalanced play with computer games fixation. At long last the specialist proposes methodology for understudies for battling computer game habit.

Keywords: Internet addiction, video game addiction, mobile addiction, video games addiction symptoms

\section{Introduction:}

Prominence of computer games is developing in the quickest way, and some narrative reports demonstrate that this sort of amusement is very addictive, some computer game players spending over 50 hours week after week playing computer games. As a result of that there is a crisis requirement for examines that research singular attribute which causes radical computer games, playing [1]. Computer recreations turn into an essential everyday action for the majority of youngsters particularly the understudies ones. With the wide accessibility of web administrations, computer games turn out to be more alluring and more well known than before [2, 3]. This issue cased a rousing term for innovative scientists spoke to buy innovation compulsion.

\section{1) Innovation Addiction: It is} characterized as "a reliance, on a movement or conduct that a man has no energy to quit doing it. This definition can be connected to any exorbitant conduct done by individuals [4]. In this examination the specialist will highlight the fixation which identified with the utilization of electronic gadget. There are distinctive sorts of innovation compulsion, we will show some of them and give a concise depiction for everyone. 1) Internet Addiction: In the new social condition, people's day by day lives and exercises identified with numerous electronic gadgets and loaded with, similar to PCs, cell phones, and tablets. Amid the day, individuals utilize many types of media exercises, for example, chatting on PDAs, messaging, playing diversions, watching recordings, checking email, or surfing the internet. The guarantees of media advancements in its new worldwide are to 


\section{ISSN :2455-0108 \\ Impact Factor : 2015-3.462 \\ INTERNATIONAL JOURNAL ONLINE OF SCIENCE}

Volume II, Issue IX December 2016

offer momentary nature, interconnectedness and convenience with a specific end goal to meet consumers` longings and requirements. Some innovation clients depend on the media which gave by these advances in unnecessary ways. Some look into demonstrating that over the top media utilize and reliance may prompt to numerous issues for people and social settings [5]. We can characterize the Problematic as an unnecessary distraction with Internet utilize that outcome in psychosocial maladjustment, physical, medical issues, and scholarly troubles for the people included). Risky Internet utilizes thought can be connected to looks into which explore addictive practices, some examination schools characterize fixation as the advancement issue that begin with immaturity [6].

2) Media Addiction: We can characterize Media enslavement with different terms, similar to: media reliance, unregulated media utilizes, tricky media utilizes, unnecessary media utilizes and urgent media utilize. A few researchers utilize the clinical term "motivation control issue" to characterize media habit and have determined that there is no inclusion of intoxicant quality. While others characterize it as mental media's reliance or mechanical fixation and consider it as a subset of behavioral enslavement $[1,4]$.

\section{3) Mobile Addiction:}

The most prevalent gadget that the vast majority utilize is cell phones, which spreading and utilized by individuals particularly youngsters. On one hand, they utilize it for their social correspondence, stimulation, and grow their chances for making social connections. Be that as it may, then again cell phone is additionally prompt to assortment of issues. For instance, for understudies in their school in the event that they utilize the cell phones this will prompt to lessen their fixation and will influence their execution, and for drivers on the off chance that they utilize the cell phones while driving it will prompt to hazardous driving propensities which cause a higher likelihood for mischances, the result of the overabundance utilization of 


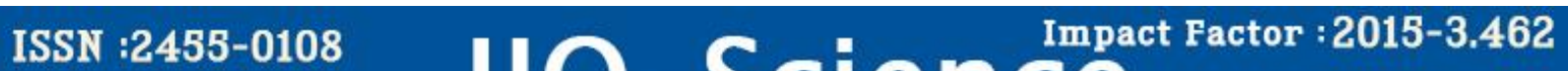

\section{INTERNATIONAL JOURNAL ONLINE OF SCIENCE}

Volume II, Issue IX December 2016

portable prompts to cell phone enslavement, there is a solid relationship between cell phones use and cell phones compulsion [7, 8]. 4) Video recreations fixation: Video amusement compulsion is a result of abundance in computer games play, some computer games have significant effect on peoples` social and prosperity by making a virtual universes for players. Despite the fact that the American Psychological Association or American Medical Association don't consider computer game habit as a "genuine" issue, and it is not delegated a clinical issue because of absence of investigates in this field. Computer game fixation is an essential space for scientists to research it inside and out with a specific end goal to locate the genuine reasons and results of this kind of compulsion and to give suggestions for individuals how to keep themselves from it and how to battle it [1]. Many explores were done in this field and demonstrated finding that present the relationship between computer games dependence and scholarly execution for understudies, the proportion of female to male gamers who are dependent, the www.ijoscience.com distinctive sorts of computer games and which sorts are the most dependent, the rate of computer games gamers who are dependent, the rate of gamers who have computer games habit signs and manifestations, lastly the child rearing styles which are related with computer games compulsion. The fundamental issue for analysts in this field is till now video recreations compulsion is not considered as a formal analysis and there is no guidelines for practices and indications that are utilized to characterize computer games enslavement, this issue may prompt to strife in discoveries and details $[1,6,13]$.

\section{Signs And Symptoms Of Video Game} Addiction

Many surveys were coordinated to find the signs and appearances of PC amusements obsession, and they compressed them in four basic classes as take after: social signs and symptoms, behavioral signs and reactions, physical signs and reactions, and mental signs and signs [9]. In this investigation, we will present the guideline signs and signs for each class. A. Social signs and symptoms 


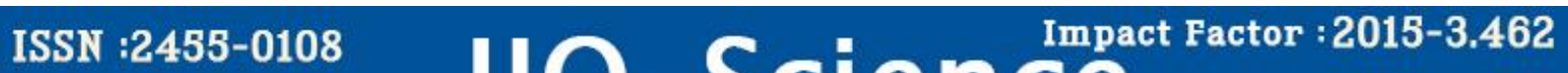

\section{INTERNATIONAL JOURNAL ONLINE OF SCIENCE}

Volume II, Issue IX December 2016

These signs related to the player relations with other some of these reactions: deluding other if they get some data about the ongoing which is proceeded with the PC amusements, rejecting social sales all together continue with PC diversions playing, reducing the time which is proceeded with friends and family, blaming others in case they bothering the gamers, relationship or matrimonial inconveniences realized by the over the top play, in conclusion losing of genuine allies while extending the amount of sidekicks in the virtual world [10]. B. Behavioral signs and appearances These symptoms related the player direct and the movements that happened to his lead in life like; reducing in academic execution, lessening the time which is appointed for inspecting and doing home works, contributing more vitality playing PC amusements, decreasing in work execution, inability to quit playing, staying up past the final turning point night with a particular ultimate objective to play, rejecting the basic commitments while playing, threatening vibe toward people who endeavor to restrict or deflect access to the www.ijoscience.com
PC diversions, spending more than 10 hours playing always, spending a ton of money on having new entertainments, playing the PC recreations and no more promptly open time , and skipping suppers while playing or eating it meanwhile of playing $[9,10]$. C. physical signs and signs These signs and symptoms related to the players body issues like; inconveniences and changes in snoozing plans, lessening in individual cleanliness, unusual or poor dietary examples, headaches, red or dryness in eyes, sore neck or fingers or back, Carpal entry issue, and weight get or shortcoming [11]. D. mental signs and reactions we will give some mental hints and symptoms which appear on the PC recreations addictive people, for instance, Feeling tense or disheartened when not playing PC diversions, Feelings of dissatisfaction and shock when not allowed to play the PC amusements, imagining about PC diversions, decreasing interests in school achievement, upholding over the top playing, losing singular control while playing PC diversions, when not online for paying just considering the accompanying 


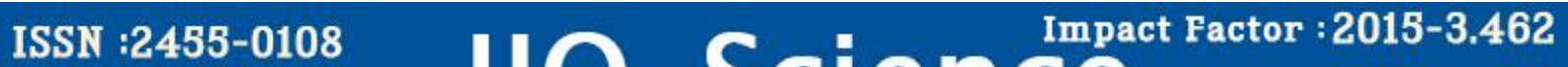

\section{INTERNATIONAL JOURNAL ONLINE OF SCIENCE}

Volume II, Issue IX December 2016

session for gaming, experiencing quietness, peacefulness, or joy while playing PC recreations, losing of interests in old acknowledged activities, and downplaying and protecting the impact of the excessive penchants in playing $[12,14]$.

The apparatus which utilized as a part of this examination was a self administrated poll. There was two fundamental areas in the survey, the first covering the specimen statistic data, and the second one intended to gather the data identified by measuring computer games dependence for understudies in Jordanian colleagues. The poll utilized shut inquiries. The survey was circulated in Arabic dialect to 780 people from Jordanian college's understudies' general public with an appropriate covering letter. The individual premise was utilized with the end goal of conveying the survey to the understudy's specimen. Likert framework was the base of the examiner to have a high level of unwavering quality. The specialist disseminated the polls and gathered them back. The quantity of polls which were gathered back was seveThe major objective of this examination is to develop a study that helping in measuring the level of PC diversions propensity for understudies in Jordanian schools. The study which used as a piece of this investigation hopes to find the relationship between each of social issue, challenges in time organization, issues in arrange life's activities, and extraordinary play with PC amusements propensity.

\section{Investigation And Discussion}

In this area the analyst will demonstrate the gathered information examination comes about, the exploration survey was routed to number of Jordanian colleges. The primary target of the poll is gathering data that aides in measuring computer game dependence for understudies in Jordanian colleges. A. Statistic Data examination 700 finished polls were keep running on SPSS for the factual investigation handle, a few respondents did not answer number of inquiries in the broke down 700 instruments. The sex of test comprises of $36 \%$ females and the staying $64 \%$ was guys. Besides, 62\% are unhitched male program understudies, $31 \%$ are ace program understudies and the rest of the $7 \%$ are doctorate program understudies. $58 \%$ of 


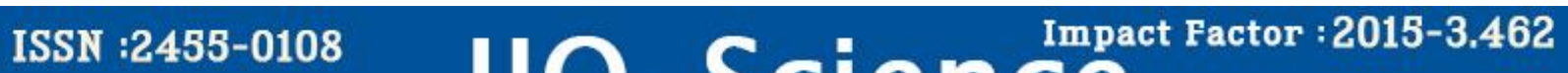

\section{INTERNATIONAL JOURNAL ONLINE OF SCIENCE}

Volume II, Issue IX December 2016

the respondents were under 25 years of age, $26 \%$ were between 25-40 years of age, and $16 \%$ were over 40 years. What's more, $67 \%$ of the respondents were single and the staying 33\% were hitched, Regarding to wage of the respondent's families $5 \%$ were less $200 \mathrm{JD}, 17 \%$ were $200-400 \mathrm{JD}, 44 \%$ were $400-700 \mathrm{JD}$ and $34 \%$ were more than 700 JD, while the respondent's resources were as per the following 32\% were from data innovation staff, $13 \%$ were from law personnel , $15 \%$ were from building workforce, $7 \%$ were from drug store workforce , 9\% were from workmanship staff designing and $24 \%$ were from back and saving money faculty. $76 \%$ of respondents trust that the Social issues is a reasonable indication of computer game dependence though $24 \%$ think it is not, while $74 \%$ trust that Difficulties in time administration is another side effect of computer game fixation and $26 \%$ don't think in this way, while $78 \%$ trust that the $\mathrm{SW}$ theft is a legitimate wrongdoing and 22 don't trust that. Moreover $81 \%$ of the respondents concur that the issues in organize life's exercises is an indication of computer games www.ijoscience.com compulsion while $19 \%$ are not concur, at long last the greater part of the example $95 \%$ trust that the extreme play is the most clear side effect of computer games habit.

\section{Recommendation:}

At long last the examination prescribes the accompanying procedure for understudies with a specific end goal to battle computer game habit. In the understudy's life, it's imperative to dispense some time for entertainment only, be that as it may, the assortment of exercises which understudies accomplish for the sake of entertainment may turn out to be more critical than some other life action, and afterward get to be as a dependence action. These habit exercises may meddle with school, college or work (the things which individuals need to do, keeping in mind the end goal to profit and accomplishment in the life). For instance it is appear enjoyable to spend all the night playing an amusement and step up in it. Be that as it may, each level in a few diversions, needs cash, these burned through cash the understudy could put it on school application or on an occupation. In this moment that the understudy wants to spend 


\section{ISSN :2455-0108 \\ Impact Factor : 2015-3.462 \\ INTERNATIONAL JOURNAL ONLINE OF SCIENCE}

Volume II, Issue IX December 2016

his cash on the diversions rather than whatever other movement, we can state that the gaming exercises and propensities turn into a compulsion. So there is a need to stop and making a stride back and perceive what you are making to yourself. Attempt to expand the time which you go through with your loved ones, they are essential in life, give the advices you need, and you can land position later from their connections. You should utilize these means till you achieve a point that you feel you would prefer not to play in a radical way.

\section{Conclusion:}

In this research paper the scientist has exhibited a diagram of web compulsion, media fixation, mobiles dependence and computer games enslavement. There is a critical relationship between the unbalanced play and computer game habit. There is a huge relationship between the issues in organizing life`s exercises and computer games enslavement. There is a critical relationship between the Difficulties in time administration and computer games fixation. they will support and help you, they will

There is a huge relationship between the Social issues and computer games enslavement. There is critical relationship between each of Social issues, Difficulties in time administration, issues in organizing life`s exercises, and extreme play and computer games fixation.

\section{References:}

[1] Hyoungkoo Khang, Jung Kyu Kim, Yeojin Kim, "Self-traits and motivations as antecedents of digital media flow and addiction: The Internet, mobile phones, and video games" Journal of Computers in Human Behavior, vol. 29, issue 6, November 2013, pages 2416- 2424. doi>10.1016/j.chb.2013.05.027

[2] John P. Charlton, Ian D. W. Danforth, "Distinguishing addiction and high engagement in the context of online game playing", Journal of Computers in Human Behavior, vol. 23, issue 3, May 2007, pages 15311548.

doi>10.1016/j.chb.2005.07.002

[3] Pyoung Won Kim, Seo Young Kim, Miseon Shim, Chang-Hwan Im, 


\section{ISSN :2455-0108 \\ Impact Factor : 2015-3.462 \\ IJO-Science \\ INTERNATIONAL JOURNAL ONLINE OF SCIENCE}

Volume II, Issue IX December 2016

Young-Min Shon, "The influence of an educational course on language expression and treatment of gaming addiction for massive multiplayer online role- playing game (MMORPG) players", Journal Computers \& Education, vol. 63, April 2013, pages 208-217.

doi>10.1016/j.compedu.2012.12.008

[4] Marloes L. C. Spekman, Elly A. Konijn, Peter H. M. P. Roelofsma, Mark D. Griffiths, "Gaming addiction, definition and measurement: A largescale empirical study", Journal of Computers in Human

Behavior, vol. 29, issue 6, November 2013, pages 2150-2155.

doi $>10.1016 / j . c h b .2013 .05 .015$

[5] Nazir S. Hawi, "Internet addiction among adolescents in Lebanon", Journal of Computers in Human Behavior, vol. 28, issue 3, May 2012, pages 1044-1053. doi>10.1016/j.chb.2012.01.007

[6] Christoph Randler, Mehmet Barış, Christian Vollmer, "Internet Addiction and Its Relationship to
Chronotype and Personality in a Turkish University Student Sample”, Journal of Social Science

Computer Review, vol. 32, August 2014, pages

484-495.

doi>10.1177/0894439313511055

[7] Afolayan Oluyinka Titilope, "SocioPsychological Dimensions of Mobile Phone Addiction and Usage Patterns amongst Teenagers in Higher Institutions of Learning in Kwara State", International

Journal of Information and Communication Technology Education, vol. 10, issue 2 , April 2014, pages 1-13. doi>10.4018/ijicte.2014040101

[8] Hyoungkoo Khang, Hyung-Jin Woo, Jung Kyu Kim, "Self as an antecedent of mobile phone addiction", International Journal of Mobile Communications, vol. 10, issue 1 , December 2012, pages

65-84. doi>10.1504/IJMC.2012.044523

[9] Fiona Fui-Hoon Nah, Brenda Eschenbrenner, Qing Zeng, Venkata Rajasekhar Telaprolu, Sepandar Sepehr, "Flow in gaming: literature 


\section{ISSN :2455-0108 \\ Impact Factor : 2015-3.462 \\ JO-Science \\ INTERNATIONAL JOURNAL ONLINE OF SCIENCE}

Volume II, Issue IX December 2016

synthesis and framework

development", International Journal of Information Systems and Management, vol. 1, issue 2, June 2014 ,

pages

83-124.

doi>10.1504/IJISAM.2014.062288

[10] Joanne S. Luciano, Grant P. Cumming, Eva Kahana, Mark D. Wilkinson, Elizabeth H. Brooks, Holly Jarman, Deborah L. McGuinness, Minna S. Levine, "Health Web Science", Journal of Foundations and Trends in Web Science, vol. 4, issue 4, October 2014, pages 269-419. doi $>10.1561 / 1800000019$

[11] Hui-Jie Tone, Hao-Rui Zhao, WanSeng Yan, "The attraction of online games: An important factor for Internet Addiction", Journal of computer in Human Behavior, vol. 30, January 2014, pages 321-327. doi>10.1016/j.chb.2013.09.017

[12] Marina Papastergiou, "Exploring the potential of computer and video games for health and physical education: A literature review", 